\title{
MODEL MIND MAPPING TERHADAP HASIL BELAJAR SISWA MATA PELAJARAN AKIDAH AKHLAK
}

\author{
M. Iqbal Al-Afghany ${ }^{1,}$ Gunawan Ikhtiono ${ }^{2}$, Syarifah $^{3}$ \\ FAI Universitas Ibn Khaldun, Jl Sholeh Iskandar, Bogor; \\ ${ }^{1}$ Mahasiswa Pendidikan Agama Islam \\ muhiqbal546@gmail.com ${ }^{1}$,
}

\begin{abstract}
Abstrak
Penelitian ini bertujuan untuk mengetahui pengaruh Model Mind Mapping terhadap hasil belajar siswa pada mata pelajaran Akidah Akhlak kelas VIII di MTsN Kota Bogor. Pada mata pelajaran Matematika di SDIT Al-Madinah Cibinong, dengan memiliki rata-rata prestasi belajar kelas eksperimen 90 dan kelas kontrol 80,5 dan karakter peduli sosial memiliki rata-rata kelas eksperimen sebesar 12,75 dan kelas kontrol memiliki rata-rata 11,8. Pendekatan yang digunakan dalam penelitian ini adalah penelitian kuantitatif dengan jenis penelitian eksperimen semu, pada penelitian ini pemilihan sampel pada quasi experimental tipe Non Equivalent Control Group Design tidak dilakukan pemilihan sampel secara random melainkan dipilih dengan sengaja oleh peneliti yaitu dengan masing-masing sampel kelas eksperimen 28 siswa dan kelas kontrol 28 siswa. Instrumen yang digunakan pada penelitian ini yaitu: tes, observasi . Jadi pendekatan Matematika Realistik dapat mempengaruhi Prestasi dan karakter peduli sosial siswa pada mata pelajaran matematika dikatakan efektif dan terdapat perubahan dan peningkatan yang signifikan.
\end{abstract}

Kata kunci: pengaruh model mind mapping, hasil belajar siswa.

\begin{abstract}
The aim of this research is to know the influence of Model Mind Mapping learning outcomes in subjects of moral creed in class for students in VIII H and I classes. On moral creed subjects at MTsN Bogor, has an average learning outcomes of experimental class 90,5 and control class 79,4. Otherwise.. The model used the quantitative approach with the type of quasi-experimental research, and also in this study the selection of samples on quasi-experimental type Non Equivalent Control Group Design for random sample selection was not carried out, but deliberately chosen by researchers, with each sample of the experimental class 28 students and the control class 28 students. The research used some instruments, are: test and observation. Therefore, Model Mind Mapping can influence the learning outcomes of students on the moral creed, it said to be effective and there were significant changes and improvement.
\end{abstract}

Keywords: influence model mind mapping, student learning outcomes.

\section{PENDAHULUAN}

Aqidah merupakan ikatan atau perjanjian yang kokoh, hal ini dapat dilihat dari arti aqidah yang berasal dari 'aqada yang artinya ikatan, simpul, perjanjian dan kokoh. Aqidah adalah apa yang diyakini seseorang dalam hati, dengan keyakinan itu hilanglah keraguan dalam hatinya karena aqidah merupakan perbuatan hati, yaitu kepercayaan hati dan pembenarannya terhadap sesuatu. (Dahlan, 2017:1) Hasil belajar adalah segala sesuatu yang menjadi milik siswa sebagai akibat dari kegiatan belajar yang dilakukannya. Hasil-hasil belajar adalah pola-pola perbuatan, nilainilai, pengertian-pengertian dan sikapsikap, serta apersepsi dan abilitas. (Jihad dan Haris, 2012 : 15). (Suwarno, 2009:21) 
Kontribusi pendidikan yang diharapkan bagi perkembangan para peserta didik tercatat dalam Undang-undang No. 20 tahun 2003 tentang pendidikan Nasional, yang berbunyi sebagai berikut. "pendidikan adalah usaha sadar dan terencana untuk mewujudkan suasana belajar dan proses pembelajaran agar peserta didik secara aktif mengembangkan potensi dirinya sehingga memiliki kekuatan spiritual keagamaan, pengendalian diri, kepribadian, kecerdasan, akhlak mulia, serta keterampilan yang diperlukan oleh dirinya, masyarakat, bangsa, dan negara." Berdasarkan pengertian tersebut, pendidikan bukan hanya memberikan pengetahuan dan keterampilan saja, tetapi juga mengembangkan sikap, menambah pemahaman dan tingkah laku seseorang atau kelompok.

Dengan adanya pendidikan seseorang dapat mengubah cara berfikir dan tingkah lakunya untuk kehidupan yang lebih baik dan dengan adanya pendidikan hendaknya mewujudkan peserta didik yang memiliki kecerdasan, baik kecerdasan spiritual, emosional, sosial, dan intelektual. Permasalahan pendidikan di Indonesia yang dihadapi saat ini selain semangat atau motivasi belajar, juga mengalami masalah dalam pembelajaran yang berdampak kepada hasil belajar siswa yang sangat kurang.

Berhasilnya tujuan pembelajaran ditentukan oleh banyak faktor, salah satunya faktor guru dalam melaksanakan proses pembelajaran, karena guru yang melaksanakan semua kegiatan pembelajaran di sekolah dalam hal kognitif, efektif maupun psikomotorik. Peran guru dalam pembelajaran sangat penting dan diharapkan guru memiliki model atau cara dan metode mengajar yang baik dan sesuai dengan konsep-konsep mata pelajaran yang akan disampaikan baik di kelas maupun di luar kelas.
Yusuf dkk (2016) dengan judul penelitian "Pengaruh Mind Map dan gaya belajar terhadap hasil belajar Matematika siswa" penelitian ini bertujuan untuk mengukur efektifitas penggunaan Mind Map terhadap siswa pada MTS Negeri Balang-Balang Kab. Gowa. Mind Map adalah salah suatu model pembelajaran yang memanfaatkan instrument yang dapat membantu memetakan isi atau materi sehingga lebih mudah dipelajari dan dianalisis. Dalam penelitian ini, tehnik pengambilan sampel digunakan adalah multiple random sampling, diperoleh 2 kelas dari kelas VIII yang ada.kemudian dilanjutkan dengan menentukan kelas kontrol dan kelas eksperimen, maka 2 kelas yang terpilih adalah kelas VIII B sebagai kelas kontrol berjumlah 41 siswa yang belajar menggunakan model pembelajaran Mind Map dan kelas VIII E sebagai kelas eksperimen berjumlah 41 siswa yang belajar dengan menggunakan model konvensional.

Model Mind Mapping memang sangat jarang digunakan oleh guru disekolah, guru hanya menggunakan metode konvensional (ceramah). Maka dari itu peneliti mencari hasil yang relevan bahwa Mind Mapping ini sangat berpengaruh baik bagi anak-anak disekolah dan siswa bisa mengungkapkan ide pikirannya melalui gagasan-gagasan dan pelajaran di kelas.

Selama ini kita mungkin menerima begitu saja pengajaran Akidah Akhlak di sekolah, tanpa mempertanyakan mengapa atau untuk apa Akidah Akhlak harus diajarkan. tidak jarang muncul keluhan bahwa Akidah Akhlak adalah pembelajaran yang membuat bosan oleh sebagian siswa. Faktor lain yang juga ikut mempengaruhi rasa bosan pada pelajaran Akidah Akhlak adalah faktor penyampaian materi yang diajarkan secara konvensional atau menggunakan metode yang sangat monoton. 
Untuk mengatasi permasalahan di atas perlu dicari suatu Model yang dapat mendukung proses pembelajaran Akidah Akhlak yang menyenangkan dan bukan menakutkan sehingga dapat meningkatkan hasil belajar siswa sekaligus mempermudah pemahaman siswa dalam pembelajaran Akidah Akhlak, solusi dari permasalahan diatas yaitu menggunakan Model Mind Mapping pada pembelajaran Akidah Akhlak, agar belajar tidak berpusat kepada guru.

Penggunaan Model Mind Mapping pembelajaran yang tepat sangat penting dalam proses pembelajaran. Karena itu sebagai guru harus bisa menggunakan Model yang sesuai dengan materi yang akan diajarkan sebagaimana umumnya guru mengajarkan materi kepada siswanya. Guru menstransfer ilmu pengetahuan kepada siswa, sedangkan siswa lebih banyak sebagai penerima.

Huda (2014:307) Mengatakan Mind Mapp bisa digunakan untuk membantu penulisan esai atau tugas-tugas yang berkaitan dengan penguasaan konsep. Ia merupakan strategi ideal untuk melejitkan pemikiran siswa. Mind Mapp bisa digunakan untuk membentuk menvisualisasi, mendesain, mencatat, memecahkan masalah, membuat keputusan, merevisi, dan mengklarifikasi topik utama, sehingga siswa bisa mengerjakan tugas-tugas yang banyak sekalipun.

Mind Mapping atau pemetaan pikiran merupakan cara kreatif bagi tiap pembelajar atau merencanakan tugas baru. Pemetaan pikiran merupakan cara yang sangat baik untuk menghasilkan dan menata gagasan sebelum mulai menulis. Meminta pembelajar untuk membuat peta pikiran memungkinkan mereka mengidentifikasi dengan jelas dan kreatif apa yang telah mereka pelajari atau apa yang tengah mereka rencanakan. (Shoimin, 2014: 105). Berdasarkan uraian di atas penulis mencoba menerapkan salah satu
Model pembelajaran, yaitu Mind Mapping untuk mengungkapkan apakah dengan Model pembelajaran Mind Mapping berpengaruh terhadap hasil belajar siswa pada materi pelajaran Akidah Akhlak. Penulis memilih Model ini karena Model ini mengkondisikan siswa dalam berfikir secara luas dan membuat siswa aktif yang diharapkan bisa membuat hasil belajar siswa. Jika siswa semangat dalam mempelajari Akidah Akhlak mereka tidak segan dalam mencari cara menyelesaikan persoalan materi pembelajaran Akidah Akhlak, karena pembelajaran Akidah Akhlak tidak jauh dari kehidupan yang sebenarnya. Dari latar belakang tersebut, maka penulis akan melakukan penelitian "Pengaruh Model Mind Mapping terhadap hasil belajar siswa pada mata pelajaran Akidah Akhlak kelas VIII di MTsN Kota Bogor".

Instrumen yang digunakan pada penelitian ini yaitu: tes, observasi. Rumusan masalah dalam penelitian ini adalah (1) pengaruh model Mind Mapping terhadap hasil belajar siswa kelas VIII MTsN Kota Bogor pada mata pelajaran Akidah Akhlak. maka dapat disimpulkan bahwa terdapat pengaruh model mind mapping yang signifikan dalam hasil belajar siswa.

\section{METODE}

(Darmadi, 2011: 202) Jenis penelitian ini merupakan eksperimen semu pemilihan sampel pada Quasi Experimental tipe Nonequivalent Control Group Design tidak dilakukan pemilihan sampel secara random melainkan dipilih dengan sengaja oleh peneliti, kelompok mana yang akan dijadikan kelompok eksperimen dan mana yang akan dijadikan kelompok kontrol. penelitian ini dilakukan di MTsN Kota Bogor terletak di jl. Achmad Sobana No 23, Tegal Gundil, kec. Bogor Utara, kota Bogor, sedangkan waktu penelitian yang penulis rencanakan dimulai 
dari tanggal 11 Juli 2019- 22 September 2019.

Dalam penelitian ini yang akan dijadikan subjek Kelas VIII terdiri dari 9 kelas VIII H sampai dengan VIII I, dalam hal ini peneliti mengambil dua kelas yaitu kelas VIII $\mathrm{H}$ dan VIII I. pada kelas eksperimen jumlah siswa terdiri dari 28 siswa dan di kelas kontrol terdapat 28 siswa. Menurut (Sugiyono 2013) dengan menggunakan teknik Random Asigment, yaitu dimana pengelompokkan subyek secara acak ke dalam kelompok eksperimen dan kelompok kontrol. Jadi peneliti memilih siswa secara acak dengan tingkat kecerdasan antara kelas eksperimen dan kontrol harus equal seimbang antara kelas satu dengan kelas yang lainnya. Dengan tujuan agar tidak terjadi ketidak setaraan dalam penelitian. Peneliti ini menggunakan 2 variabel yang pertama menggunakan bebas dan variabel terikat. Dimana variabel terikat itu meliputi hasil belajar.

Peneliti telah melakukan uji coba instrumen pada siswa kelas VIII dengan siswa berjumlah 28 orang siswa dan 20 soal tes instrumen penelitian. Untuk dapat dikatakan baik sebagai alat pengukur atau evaluasi maka melakukan validitas dan reliabilitas.

\begin{tabular}{|c|c|c|c|c|c|}
\hline $\begin{array}{l}\text { Nomor } \\
\text { Item }\end{array}$ & Person Correlations & status & Nomor Item & Person Correlations & Status \\
\hline 1 &, 100 & Tidak Valid & 21 & ,571 & Valid \\
\hline 2 & ,404 & Valid & 22 & ,506 & Valid \\
\hline 3 & ,492 & Valid & 23 & ,266 & Tidak Valid \\
\hline 4 & ,404 & Valid & 24 & B & Tidak Valid \\
\hline 5 & ,069 & Tidak Valid & 25 &, 521 & Valid \\
\hline 6 &, 451 & Valid & 26 & ,193 & Tidak Valid \\
\hline 7 & ,560 & Valid & 27 & ,520 & Valid \\
\hline 8 & ,548 & Valid & 28 & ,319 & Tidak Valid \\
\hline 9 & ,560 & Valid & 29 & ,266 & Tidak Valid \\
\hline 10 & ,794 & Valid & 30 & B & Tidak Valid \\
\hline 11 & ,549 & Valid & 31 & ,003 & Tidak Valid \\
\hline 12 & , 100 & Tidak Valid & 32 & ,407 & Valid \\
\hline 13 &, 415 & Valid & 33 &, 405 & Valid \\
\hline 14 & B & Tidak Valid & 34 & ,058 & Tidak Valid \\
\hline 15 &, 232 & Tidak Valid & 35 & ,032 & Tidak Valid \\
\hline 16 &, 519 & Valid & 36 &, 032 & Tidak Valid \\
\hline 17 & ,094 & Tidak Valid & 37 & ,404 & Valid \\
\hline 18 &, 560 & Valid & 38 & ,071 & Tidak Valid \\
\hline 19 & ,339 & Tidak Valid & 39 &, 412 & Valid \\
\hline 20 & ,436 & Tidak Valid & 40 & 1 & Tidak Valid \\
\hline
\end{tabular}

Realiabilitas dalam penelitian kuantitatif adalah kekonsistenan suatu alat ukur, atau keajegan. Alat ukur akan dikatakan reliable bila mampu membedakan siswa yang pintar dengan siswa yang kurang pintar. Bisa juga bila alat ukur digunakan oleh orang yang sama pada waktu yang berbeda skornya tidak jauh beda. Bisa juga bila suatu alat ukur digunakan untuk orang yang taraf kecerdasannya sama akan memperoleh skor yang relatif sama. reliabilitas dilakukan dengan menggunakan software 
SPSS 20, dengan analisis Reliability analyze.

Reliability Statistics

\begin{tabular}{|r|rr|}
\hline \multicolumn{2}{|c|}{ Cronbach's Alpha } & N of Items \\
\hline &, 557 & \\
\hline
\end{tabular}

Berdasarkan hasil uji reabilitas dapat disimpulkan bahwa terdapat nilai dapat diperoleh nilai reabilitas sebesar 0,557 . Hal tersebut menunjukkan bahwa hasil reabilitas lebih besar dari $r$ tabel sebesar 0,05 jadi disimpulkan bahwa semua soal yang valid dinyatakan sudah reabel.

\section{HASIL PENELITIAN}

Untuk mengetahui hasil dari penelitian ini, peneliti menyajikan secara urut meliputi deskripsi umum hasil penelitian, dan pembahasan yang menjelaskan pengaruh model mindp mapping terhadap hasil belajar siswa pada mata pelajaran Akidah Akhlak kelas VIII di MTsN Kota Bogor. Peneliti menggunakan data yang diperoleh dari hasil penyebaran Tes soal pre-tes dan posttes kepada kelas VIII H dan kelas VIII I agar menghasilkan data yang relevan.

Dari data-data penelitian yang telah dianalisis, di peroleh data hasil belajar siswa pada kelas eksperimen dan kelas kontrol. Dapat disimpulkan bahwa terdapat perbedaan rata-rata kedua kelas tersebut dengan nilai rata-rata kelas eksperimen pre-test 58,92 dan post-test 90,5. Sedangkan kelas kontrol mendapatkan nilai rata-rata pre-test 44,6 dan post test 79,4 . dapat disimpulkan bahwa terdapat perbedaan yang signifikan antara kedua kelas tersebut dimana kelas eksperimen jauh lebih unggul dibandingkan dengan kelas kontrol. Hal tersebut karena kelas eksperimen menggunakan Model Mind Mapping sedangkan kelas kontrol menggunakan pendekatan konvensional (ceramah). Pada hasil tes simple paired prestasi belajar dari tes simple paired kontrol dan eksperimen.

Berdasarkan hasil perhitungan diatas dengan menggunakan Paired Sample t test dengan aplikasi SPSS 20 di kelas eksperimen, diperoleh hasil t hitung adalah $-13,918$ dengan (df) data frekuensi (n-1) yaitu 28-1 yaitu 27. Pengambilan keputusan melihat hasil sig. (2-tailed) adalah 0,000. Berdasarkan hasil perhitungan diatas dengan menggunakan Paired Sample t test dengan aplikasi SPSS 20 di kelas eksperimen, diperoleh hasil $t$ hitung adalah -20,006 dengan (df) data frekuensi (n-1) yaitu 28-1 yaitu 27. Pengambilan keputusan melihat hasil sig. (2-tailed) adalah 0,000. Hal ini menunjukan bahwa angka tersebut lebih kecil dari 0,05.

Berdasarkan

perhitungan independent sample $\mathrm{t}$ test pada kelas eksperimen dan kelas kontrol diperoleh hasil $\mathrm{t}$ hitung adalah -18,731 dengan jumlah siswa 28 orang. Pengambilan keputusan ini melihat hasil sig. (2-tailed) adalah 0,000 hal ini menunjukkan bahwa angka tersebut lebih kecil dari 0,05, keputusan tersebut didasari oleh sig. (2tailed) lebih kecil dari 0,05 atau $\mathrm{Ha}$ diterima, maka terdapat perbedaan yang signifikan antara nilai rata-rata post-test kelas eksperimen dan kelas kontrol. Dapat disimpulkan bahwa terdapat peningkatan hasil belajar siswa.

Pada kelas kontrol yang diberikan pembelajaran dengan menggunakan pendekatan konvensional (ceramah), pada saat pembelajaran dimulai, siswa diberikan test awal terlebih dahulu sama seperti kelas eksperimen untuk mengetahui 
pemahaman siswa terhadap pelajaran Akidah Akhlak. Sedangkan test akhir diberikan kepada siswa, setelah diberikan pemahaman dan materi tentang pecahan sederhana. Pendekatan konvensional hanya memberikan penjelasan materi saja yang bersifat monoton dan siswa hanya memperhatikan saja. Sehingga tujuan pembelajaran tidak tercapai sesuai dengan yang diharapkan.

Sedangkan di kelas eksperimen dengan menggunakan Model Mind Mapping, pada saat proses pembelajaran dimulai, sama seperti kelas kontrol siswa diberikan test awal terlebih dahulu setelah itu diberikan perlakuan dengan menggunakan Model Mind Mapping . Dalam Model ini proses pembelajaran menggunakan permasalahan dengan mengemukakan gagasan atau ide pikiran sendiri yang dimana siswa dapat mempersentasikan hasil dari belajar. dan dapat dibayangkan oleh siswa agar siswa dapat menyelesaikan masalah dan bisa dibayangkan oleh siswa selanjutnya pada pertemuan kedua hanya ada hanya ada beberapa siswa yang berada pada kualifikasi mulai terlihat, pada pertemuan ketiga terlihat $50 \%$ yang mencapai kualifikasi terlihat dan sebagiannya lagi masih pada kualifikasi belum terlihat.

Sedangkan pada kelas eksperimen, untuk pertemuan pertama yaitu sebelum diberi perlakuan menggunakan model Mind Mapping tidak ada yang berada pada kualifikasi yang terlihat, setiap pertemuannya terdapat peningkatan yang pada awal pertemuan pertama masih belum terlihat, ketika pertemuan kedua ada beberapa siswa yang berada pada kualifikasi mulai terlihat kemudian pada pertemuan ketiga sebagian siswa mulai mengalami peningkatan model Mind Mapping hampir seluruh siswa sudah mencapai kualifikasi sangat terlihat dan menjadi suatu kebiasaan siswa artinya siswa telah mengalami peningkatan perilaku yang sesuai dengan indikator yang telah diamati hasil belajar siswa pun ikut meningkat.

Dengan demikian dapat disimpulkan bahwa terdapat perbedaan antara data kedua kelas tersebut dimana kelas eksperimen lebih signifikan serta lebih unggul dibandingkan dengan kelas kontrol. Hal tersebut karena kelas eksperimen mendapatkan perlakuan dengan menggunakan Model Mind Mapping dibandingkan dengan kelas kontrol yang hanya menggunakan pendekatan konvensional. Selanjutnya pada pertemuan kedua hanya ada hanya ada beberapa siswa yang berada pada kualifikasi mulai terlihat, pada pertemuan ketiga terlihat $50 \%$ yang mencapai kualifikasi terlihat dan sebagiannya lagi masih pada kualifikasi belum terlihat.

\section{KESIMPULAN}

1. Berdasarkan penelitian di MTsN Kota Bogor terdapat beberapa faktor hasil belajar dalam pembelajaran Akidah Akhlak di kelas VIII, kurangnya alat media dan bahan ajar untuk guru, guru hanya memberikan tugas-tugas dalam buku LKS saja, guru memberikan hafalan setiap mata pelajaran Akidah Akhlak kepada siswa, guru menggunakan Pendekatan, model, metode konvensional yang bersifat monoton terhadap pembelajaran di dalam kelas, interaksi siswa dan guru sangatlah kurang, tidak diperhatikan oleh keluarga dirumah, kurangnya guru memperhatikan anak terhadap pembelajaran Akidah Akhlak, dan mengakibatkan kurangnya hasil belajar siswa di MTsN Kota Bogor pada pelajaran Akidah Akhlak.

2. Penerapan Model Mind Mapping ini dalam pembelajaran Akidah Akhlak di MTsN Kota Bogor, bertujuan untuk mengetahui perbedaan kemampuan berpikir kreatif, logis dalam pembelajaran Akidah Akhlak, anak 
lebih memahami dan mengetahui dalam pembelajaran.

3. Berdasarkan penelitian yang telah dilakukan, menghasilkan hasil t hitung adalah -7.033 dengan (df) data frekuensi (n-1) yaitu 28-1 yaitu 27. Pengambilan keputusan melihat hasil sig. (2-tailed) adalah 0,000. Hal ini menunjukan bahwa angka tersebut lebih kecil dari 0,05. Untuk keputusan tersebut didasari oleh sig. (2-tailed) lebih kecil dari 0,05 atau Ha diterima. Maka terdapat perbedaan yang signifikan antara nilai rata-rata pre-test dan Post-test hasil belajar siswa. Sedangkan jika sig. (2-tailed) lebih besar dari 0,05 maka Ha diterima dan Ho ditolak. Dapat disimpulkan bahwa pengaruh Model Mind Mapping lebih signifikan terhadap hasil belajar siswa, dibandingkan dengan sebelumnya yang dimana siswa kurang memahami belajar Akidah Akhlak dengan menggunakan alat media yang bersifat monoton.

\section{DAFTAR PUSTAKA}

Andri, " Analisis Faktor-faktor yang Mempengaruhi Rendahnya Prestasi Belajar Siswa Pada Mata Pelajaran Matematika Di SD Negeri 04 Bati Tahun Pelajaran 2016/2017" Jurnal Pendidikan Dasar PerKhasa, vol 3, No 2, Oktober 2017.

Dahlan, (2016. ) "Konsep Pembelajaran Aqidah Akhlak" Yogyakarta: PT. Deeppublish,

Hamid Darmadi, (2011.)"Metodologi Pendidikan", Bandung: Alfabeta.

Huda, Miftahul., (2013) "Model-model pengajaran dan Pembelajaran" Yogyakarta: PT. Pustaka Pelajar,

H.Rostina Sundayana, (2014) “ Media dan Alat Praga dalam Pembelajaran Matematika", Bandung; PT Alfabeta..

Sutarto Hadi, (2017),"Pendidikan Matematika Realistik Teori Pengembangan dan
Implementasinya”, Jakarta; PT. Raja Grafindo Persada.

Wiji Suwarno, (2009),'Dasar-dasar Ilmu Pendidikan", Jogjakarta; PT. Arruz Media Group. 